\title{
Addressing Global and National Concerns into Local Actions: Reflecting Customary Institution's Involvement in Combating Drug Abuses
}

\author{
Anak Agung Ngurah Wirasila* \\ Faculty of Law Udayana University, Bali-Indonesia \\ Jana Takáčová ** \\ Faculty of Law, Comenius University, Bratislava-Slovakia \\ Article Received: 30 ${ }^{\text {th }}$ December 2018; Accepted: 28 ${ }^{\text {th }}$ January 2019; Published: $31^{\text {st }}$ January 2019

\begin{abstract}
The massive movement of transnational drug-dealers has now been approaching society at the lowest level. This article is aimed at exploring how customary institution in Bali-Indonesia, namely desa pakraman (customary village) is involved in any efforts of combating drug abuse, as a complementary means of the official measures taken by Indonesian agencies that responsible for this matter. It is legal research that inquiries relevant legal documents. Besides, it discovers customary village leaders opinion by using informant interview questionnaires as well as impression obtained from direct observation. This paper discovers that there have been many customary villages modified their customary rule by incorporating the norms on prohibition of the use and sale of narcotics as well as adopted customary sanction to be imposed on those who violate it. This article also suggests that the involvement of customary institution may be used as a lesson learned regarding how the non-state actors, especially a community-based institution, may play a role to support the government in the eradication of drug abuses and crimes.
\end{abstract}

Keywords: Drug Abuses; Combat; Customary Institution; Village

How to cite (Chicago-16th): Wirasila, Anak Agung Ngurah, and Jana Takáčová. "Addressing Global and National Concerns into Local Actions: Reflecting Customary Institution's Involvement in Combating Drug Abuses." Udayana Journal of Law and Culture 3, no. 1, 30-52. https://doi.org/10.24843/UJLC.2019.v03.i01.p02.

doi: https://doi.org/10.24843/UJLC.2019.v03.i01.p02

\footnotetext{
* Email/Corresponding Author: ngurah_wirasila@unud.ac.id

** Email: jana.takacova55@gmail.com
} 


\section{Introduction}

\subsection{Background}

"Bali is currently in an emergency situation of drug abuse!" This statement was repeatedly spoken by government officials, politicians, and activists. ${ }^{2}$ It is, of course, not a surprising fact as data shows an increasing number of drug cases in Bali. This can be seen from the increasing trend of 120 percent drug cases in Denpasar, the capital of Bali in 2018, comparing to the year of 2017. ${ }^{3}$ Besides, the Integrated Service Center for the Protection of Women and Children discovered that it handles cases in which 70 percent of them are about drugs, and the most common case is that children become drug couriers. ${ }^{4}$ These facts strengthen the general opinion that the more Bali opens for global tourism, the more risk of negative impact of tourism and transnational activities, such as drugs circulation, would potentially endanger the locals.

The national government, especially through the National AntiNarcotics Agency of the Republic of Indonesia (Badan Narkotika Nasional/BNN), has made a set of efforts to overcome this problem. This including some criminal law enforcement measures that have been taken to perpetrators. Some severe types of the sentence imposed on the perpetrators, including a death penalty, in facts, do not effectively decrease the numbers of drug abuse. The government then looks at some alternative approaches in complementing its programs.

One of the alternative approaches used by the BNN is to make a collaboration with a religious organization in disseminating that drug abuse is a behavior that contrary to religious values. In 2017, BNN published a book that describes the Hindu religious views about the dangers of drug abuse by citing Hindu holy books of Bhagavadgita and Sarasamuscaya. ${ }^{5}$ In line with this efforts, a Balinese-Hinduism leader also expressed his views that according to Hindu belief, the drug can be classified as a poison that

2 Bali Darurat Narkoba? 1.488 Desa Diminta Bentuk Perarem Narkoba. TribunBali.com. Last modified August 22, 2017. http://bali.tribunnews.com/2017/08/22/balidarurat-narkoba-1488-desa-diminta-bentuk-perarem-narkoba

3 Busrah Ardans, Angka Kasus Narkoba di Denpasar Naik 120 Persen, Ini Penjelasan Pihak Polda Bali. Tribun Bali.Com. Last modified August 16, 2018. http://bali.tribunnews.com/2018/08/16/angka-kasus-narkoba-di-denpasar-naik-120persen-ini-penjelasan-pihak-polda-bali

${ }^{4}$ I Wayan Erwin Widyaswara, Peredaran Narkoba di Bali Kian Mengkhawatirkan, Anak-anak Jadi Kurir Narkoba, Tribun Bali.Com. Last modified July 31, 2018. http://bali.tribunnews.com/2018/07/31/peredaran-narkoba-di-bali-kianmengkhawatirkan-anak-anak-jadi-kurir-narkoba

${ }^{5}$ I Putu Suhartama and BNN Team. Pandangan Agama Hindu Tentang Bahaya Penyalahgunaan Narkoba. (Jakarta: Deputi Bidang Pencegahan Badan Narkotika Nasional, 2017), 22-27. 
can kill persons, in which the user may lose his/her character and identity as a human being. ${ }^{6}$

Another unique alternative approach is to involve desa pakraman (hereinafter refer to as customary village) to work hand in hand with the government to address this issue. In July 2018, a customary village, Desa Pakraman Jelekungkang, Taman Bali, Bangli Regency was declared as 'A Drugs Clean Area' by The Republic of Indonesia State Police, Bangli Police Resort. This customary village is one of the religious-tourism villages that was appreciated for its community commitment to fight drug trafficking. ${ }^{7}$ An extreme idea stated by Head of Jembrana Regency I Putu Artha. He did not only urge customary village to include drug abuse into the rule of the customary village but also proposed that the drug abuser must be imposed a sanction of kasepekang, a kind of exclusion, as an ultimum remedium punishment recognized by Bali Customary Law. ${ }^{8}$

The enactment of Regulation of Bali Province Number 7 of 2017 Concerning Facilitation of Prevention of Narcotics Abuse intentionally includes customary village as one of the main pillars in preventing narcotics abuse in Bali. In addressing this issue, through this regulation, customary village is expected to participate in a series of community empowerment as well as collaborate with the government in addressing this issue.

A legal issue arises as this regulation enable Governor to advice customary villages in Bali to transform the legal content of drug prevention into their customary rules called awig-awig and perarem. These customary rules are made by and applied to the customary community in a certain village in Bali that, in facts, exist along with national law adopted by the official government. It is a unique situation in which the customary village members have to obey both customary rules and official laws made by Indonesian governments, due to facts that members of the customary community are also a citizen of Indonesia.

The intention to insert drug prevention into awig-awig and perarem was widely expressed even before the provincial regulation was created. Head of

\footnotetext{
6 PHDI Jembrana dukung penyalahgunaan narkotika masuk peraturan adat. Antaranews.com. Last modified October 2018. https://bali.antaranews.com/berita/132558/phdi-jembrana-dukung-penyalahgunaannarkotika-masuk-peraturan-adat

7 Penetapan desa pakraman jelengkung sebagai desa bersih narkoba. $\begin{array}{lllll}\text { Balitribune.co.id. Last } & \text { modified } & \text { October } & 3, & \end{array}$ http:// balitribune.co.id/content/penetapan-desa-pakraman-jelengkung-sebagai-desabersih-narkoba

8 PHDI Jembrana dukung penyalahgunaan narkotika masuk peraturan adat. Antaranews.com. Last modified October 2018. https:/ / bali.antaranews.com/berita/132558/phdi-jembrana-dukung-penyalahgunaannarkotika-masuk-peraturan-adat and Mantap! Dua Kilogram Sabu dan Ribuan Pil Koplo Dimusnahkan Kejari Jembrana. Baliberkarya.com. Last modified September 28, 2018. https://baliberkarya.com/index.php/read/2018/09/28/201809280003/Mantap-DuaKilogram-Sabu-dan-Ribuan-Pil-Koplo-Dimusnahkan-Kejari-Jembrana.html
} 
the Head of the Empowerment of Society and Village Government, Bali Province Ketut Lihadnyana agreed if the BNN involved village officials for drug prevention. He reflected successful government program, namely family planning, that approach local content have involved customary villages. ${ }^{9}$ In facts, there has been a successful program namely village free from narcotics, initiated by BNN. The cooperation between BNN and Customary Village was supported by Governor of Bali. ${ }^{10}$

In 2017, some 42 customary villages in Badung regency have incorporated the anti-narcotics provisions into their perarem. ${ }^{11}$ Recently, as of November 2018, there have been 16 customary villages in Gianyar Regency that created anti-narcotics perarem. ${ }^{12}$ The perarem of Banjar Adat Sampiang, Gianyar regency can be used as an example Article 72 (8) of this perarem explicitly prohibits its members or other people are prohibited to keep, use and circulate drug. Those who violate this rule can be fined IDR 500.000 (currently, equivalent to US\$ 35) and conduct prascita gumi ceremony, following the guidance of the sulinggih (Hindu-Bali priest). ${ }^{13}$

There are two issues that appear in the current situation. First of all, there are two entities, namely the State of Indonesia as represented by national and local governments as well as BNN and the customary institution, that may be joining in addressing the drug abuse. The second issue is there are two different legal systems, namely the State law (of Indonesia) and customary law (of Bali) that will be used as instruments to overcome drug abuse. The formal national and local law and regulations, issued by authoritative state organs and officials, have already been existed but remaining not fully effective yet. ${ }^{14}$ If looking back at the history, before

9 Bali Darurat Narkoba? 1.488 Desa Diminta Bentuk Perarem Narkoba. Tribun Bali.Com. Last modified August 22, 2017. http://bali.tribunnews.com/2017/08/22/balidarurat-narkoba-1488-desa-diminta-bentuk-perarem-narkoba

10 Perarem Anti Narkoba Persempit Ruang Gerak Pengedar di Desa Pekraman. $\begin{array}{lllll}\text { Beritabali.com. Last } & \text { modified }\end{array}$ https:/ / beritabali.com/read/2018/11/15/201811150015/Perarem-Anti-NarkobaPersempit-Ruang-Gerak-Pengedar-di-Desa-Pekraman.html

11 Suyatra, I Putu. Sudah 42 Desa di Badung Masukkan Narkoba ke Awig-Awig dan Pararem. baliexpress.jawapos.com. Last modified November 22, 2017. https://baliexpress.jawapos.com/read/2017/11/22/28579/sudah-42-desa-di-badungmasukkan-narkoba-ke-awiq-awig-dan-pararem

12 Nusa Bali. BNN Resmikan 7 Desa Bebas Narkoba dan 16 Perarem Anti Narkoba di Gianyar. Skanaa.com. Last modified November 16, 2018. https://www.skanaa.com/en/news/detail/bnn-resmikan-7-desa-bebas-narkoba-dan-16perarem-anti-narkoba-di-gianyar/nusabali

${ }_{13}$ I Made Sumada, Op.Cit, 513 and 10 Desa Pakraman Ditarget Punya Pararem Anti Narkoba. Nusabali.com. Last modified June 23, 2018. https://www.nusabali.com/berita/32557/10-desa-pakraman-ditarget-punya-pararemanti-narkoba

${ }^{14}$ Suhendi Adi. Hukum Adat Lebih Ditakuti Warga Bali Dibanding Hukum Positif. Tribunnews.com. Last modified March 2014. http://www.tribunnews.com/nasional/2014/03/06/hukum-adat-lebih-ditakuti-wargabali-dibanding-hukum-positif 
the Law of the Republic of Indonesia No.9 year 1976 concerning Narcotics was enacted that clearly establish crime of narcotics, the criminalization for drug abuser or dealers used to refer to Article 204 of the Indonesian Criminal Code) that punish those who sells, offers for sale, delivers or distributes goods, knowing that they are harmful to life or to health and conceals said harmful nature. After the Law of the Republic of Indonesia No. 35 the Year 2009 concerning Narcotics was enacted, in which the crime on narcotics have been further advanced, some norms contained in Indonesian Criminal Code regarding participation in punishable acts, such as Article 55 (penyertaan /deelneming) and Article 56 on aiding (pembantuan/medeplichtigheid), were still used. The existence of those formal laws, again, do not significantly decrease any drug abuses and crimes. Therefore, in order to strengthen such formal law, some alternative ideas and measures are tried. One of the alternative ideas, that has already been implemented in practice, was to create customary law that is made by, and applied for, a customary community in Bali, which regulates the rule and punishment for any drug abuses.

\subsection{Purpose}

The idea behind this writing is to alternate the common perception that views the eradication of drug abuses and crimes are the exclusive domain of State and would only be effectively implemented by government programs and measures as well as international cooperation. Besides, this paper would like to reveal that customary law in form of awig-awig and perarem that created and adopted by the customary community may have relevance to strengthen the national law and regulation on narcotics eradication.

Therefore, this article aims to analyze the needs to use an alternative approach to combating drug abuse. In particular, it explores how customary institution in Bali-Indonesia, namely desa pakraman (customary village) may be involved in any efforts of eradicating drug abuse, as a complementary means to support measures taken by Indonesian agencies that responsible for this matter.

\subsection{Method}

The present article is legal research that inquiries legal documents on the topic discussed. It analysis some Indonesian legislation at the national and local level besides law and regulation of other countries, as a comparison, and international instruments. Some primary information was obtained from the informant interview questionnaire circulated to some customary village leaders (Bendesa and Klian) in Bali between NovemberDecember 2018. The result of questionnaires showed the knowledge, perception, expression, and expectation of customary village leaders regarding the efforts to combat drug abuse in general and in a specific issue 
that is the involvement of the customary community. ${ }^{15}$ Besides, arguments were also built from direct observation by authors.

This article is presented by an assumption that local efforts of combating drug cannot be separated from national and global works. Therefore, the analysis is begun by firstly exploring the concern of international society in dealing with such all human being threat that can be seen from the creation of international legal instruments, the role of the international organization, and state practices. It will then continued by the description of the Indonesian national law and regulation. The central issue of this writing is analyzed in Section 2.3.

\subsection{Literature Review}

In Indonesia, the activity of using drugs or narcotics is generally known as nyandu or madat. It should be clarified that this paper does not make a strict definition or the legal or conceptual meaning of specific words and phrases. For example, the term 'drugs' and 'narcotics' for some experts may be understood differently as well as some legal documents that define those terms in a different way. Both 'drugs' and narcotics' are used interchangeably in this article. It also does not specifically focus on one issue among several steps or measures in overcoming drug problems, for example, pre-emption, prevention, repression, criminalization, rehabilitation, or social reintegration. This article is intentionally intended to explore how wide the customary community may be involved in addressing the issue of drug abuse.

Studies show that the local community would be given a role in the process of social rehabilitation for those who have been rehabilitated. To achieve a major goal is to integrate a person into society, it is the responsibility for organizing rehabilitation programmes falls primarily on the social and welfare authorities and voluntary associations in the local community 16

Muhamad Amin Imran studies the functional relationship between BNN and Lembaga Kemasyarakatan (Correctional Institutions/Penitentiary) in dealing with the issue of narcotics at correctional facilities. ${ }^{17}$ The reality is that the existence of the Memorandum of Understanding (MoU) that has been established at the national level does not have a positive impact on the sustainability of agency cooperation in the prevention and eradication of

15 List of Informant is provided in Section 2.3.3

16 Bror Rexed, Ken Edmondson, Inayat Khan, and Robert J. Samsom. "Guidelines for the Control of Narcotic and Psychotropic Substances: In the Context of the International Treaties." (Geneva: WHO, 1984), 107

17 Muhamad Amin Imran, Hubungan Fungsional Badan Narkotika Nasional dengan Lembaga Pemasyarakatan dalam Penanganan Narkotika di Lembaga Pemasyarakatan. Jurnal IUS-Kajian Hukum dan Keadilan 1, no. 2 (2013): 327-345. 
illicit drug trafficking in the regions. ${ }^{18}$ This suggested by a recent empirical study that was conducted by Risa Andika Sari et.al that analyze the integrated prevention and suppression efforts of drug abuses at the penitentiary, by observing two correction facilities in the Province of Aceh, Indonesia. 19 The research suggested that such efforts have not been optimally worked, as there is no synergic relationship between related institutions (Correction Institution, Police and BNN) as they did not establish good communication and coordination. ${ }^{20}$ Besides, some obstacles were faced with e.g information leakage, the involvement of officers, criminal procedures, lack of budget and infrastructure. ${ }^{21}$

A study focuses on decriminalization policy to decrease the number of victims of drug abuse. ${ }^{22}$ It concluded that such policy programs have not been effective in breaking the chain of drug circulation in Indonesia due to some factors, e.g. a very long coastline of Indonesia that leads to inability of BNN to perform surveillance, especially at small ports and lack of law enforcement. ${ }^{23}$

Restiana Pasaribu conducting research concerning the strengthening of the community to fight narcotics by specifying its research on Community Policing in Semarang. She considers that community policing serves as one of the strategies in using the preemptive and preventive approach in the handling of crime. However, in one spot she discovered that the works of Bhayangkara Pembina Keamanan dan Ketertiban Masyarakat (Bhabinkamtibmas) seems not so optimal yet due to concerns of structural, resources, budget, and cultural aspects. ${ }^{24}$

Research carried out by I Made Sumada ${ }^{25}$ discusses the quite similar topic with the present article. It focuses on the issue of the collaboration between the National Narcotics Agency's policy with perarem of the customary village in Bali in handling drug abuse. ${ }^{26}$

18 Risa Andika Sari, Suhaimi, and Muazzin. "Upaya Terpadu Pencegahan dan Pemberantasan Penyalahgunaan Peredaran Gelap Narkotika di Lapas Klas II A Banda Aceh dan Rutan Klas II B Sigli." Syiah Kuala Law Journal (SKLJ) 2, no. 1 (2018):162.

19 Ibid, 155-156.

20 Ibid, 168-169.

21 Ibid, 162-169.

${ }^{22}$ Haniyah and M. Hidayat. Juridical Review of Decriminalization on Efforts to Cut Drugs Users' Addiction In Indonesia. Yurisdiksi: Jurnal Wacana Hukum dan Sains 11, no.1 (2018): 3 .

23 Ibid, 10-11.

24 Restiana Pasaribu, Fight Narcotics With Community Strengthening: Crime Control Management by Community Policing. Journal of Indonesian Legal Studies 3, no.2 (2018): 249.

25 I Made Sumada, "Collaboration Policy of Regional Office of National Anti-Narcotics Agency with Local Wisdom (Perarem Desa Pekraman) in Bali Handling Drug Abuse." In International Conference on Business, Economic, Social Science and Humanities (ICOBEST 2018). Atlantis Press, 2018: 510-514

26 Ibid, 511. 


\section{Result and Discussion}

\subsection{Global Efforts to Overcome Drug Abuse}

Over the last decade, we can see rapid social and economic development which created an appropriate environment for drug abuse in many countries all around the world. It is not a problem of one or two countries, but its nature has turned out to be transnational.

It can be simply argued that this transnational problem goes beyond the capacity of the state as national organizations and institutions cannot manage it through its own resources and legal channels. The options that remain at the state's disposal are either a wider multilateral and global governance approach or covert operations that would be deemed a violation of international law.

It now becomes clear that the drug abuse problem has become an international concern. In this regard, some international organizations, primarily the United Nations (UN), play a role to overcome this problem. As an instance, the United Nations Office on Drugs and Crime (UNODC) makes an annual report regarding global data related to drugs. The report covers the issue of drug abuse analysis, which also includes the impact on social and economic development as well as a rising threat. According to UNDOC World Drug Report 2018, about 275 million people worldwide (5.6 percent of the global population) aged 15-64 years, used drugs at least once during 2016. The World Health Organization (WHO) also pays its attention to the problem of drug abuses. WHO released that around 450,000 people died as a result of drug use in 2015, in which 167,750 of them were directly associated with drug use disorders (mainly overdoses). ${ }^{27}$

Within the UN there is also the Commission on Narcotic Drugs that has a mandate, as expanded by the United Nations General Assembly, to enable it to function as the governing body of the UNODC that exercises the administrative and financial functions entrusted to it by the General Assembly. The main function of this commission is to approve the programme budget for the Fund of the United Nations International Drug Control Programme made according to report of UNODC. In practice, UNODC conducted joint activities to include a human rights-based approach in national drug policy that, among others, strengthening the capacities of communities and promoting the involvement of social actors. ${ }^{28}$

27 UNODOC. Executive Summary Conslusions and Policy Implications. World Drug Report 2018. Austria: United Nations Publications, 2018. https://www.unodc.org/wdr2018/prelaunch/WDR18_Booklet_1_EXSUM.pdf

28 UNODOC. International cooperation against the world drug problem Report of the Secretary-General to the United Nations General Assembly A/73/135. United Nations Publications, 1999. https://www.unodc.org/documents/commissions/CND/Drug_Resolutions/19901999/1999/ECOSOC_Res-1999-30.pdf 
Another international organization that is also very proactive in drug abuse problem is the European Union, which currently has 28 members. Its agency called European Monitoring Centre for Drugs and Drug Addiction (EMCDDA) was established in 1993 to provide factual, objective, reliable and comparable information on drugs and drug addiction. The responsibilities of EMCDDA is to: 29

- monitor the drugs problem in Europe (including emerging trends)

- monitor solutions applied to drug-related problems

- provide information on best practice in EU countries and encourages them to share it

- assess the risks of new psychoactive substances

- run an early warning system on new psychoactive substances

- develop tools and instruments to help EU member states monitor and evaluate their national policies and the European Commission to monitor and evaluate EU policies.

In order for this agency to be able to show the results every year, there is a need for more consultations with other agencies of the European Union. The EMCDDA and these EU agencies produce joint publications, services, and initiatives. For example, the EMCDDA works with Europol and the European Medicines Agency to operate the EU Early Warning System on New Psychoactive Substances.

A European approach to addressing drugs sustainably have been developed by the European Union and its member states. Such an approach is laid down in the EU Drugs Strategy 2013-2020 and two consecutive fouryear Action Plans on Drugs. In implementing the EU drugs policy, Civil society, especially NGOs, becomes an important partner. A Civil Society Forum on Drugs (CSF) was also created as a particular consultative body. ${ }^{30}$

A state practice may be observed from the Slovak Republic, a small country located in Central Europe and a member of the EU, with a population around 5.000.000 inhabitants. Drug abuse is also a major problem in the Slovak Republic. Slovak young people, aged 15-34 years, mostly used cannabis. 31

Under the conditions of the Slovak Republic, any possession of drugs is considered a criminal offence. According to Section 172 of the Penal Code, the punishments are different according to the amount of drug possessed:

29 European Union. European Monitoring Centre for Drugs and Drug Addiction (EMCDDA). europa.eu. https://europa.eu/european-union/about-eu/agencies/emcdda_en 30 European Union, Migration Affairs, EU's Response to Drugs, https://ec.europa.eu/home-affairs/what-we-do/policies/organized-crime-and-humantrafficking/drug-control/eu-response-to-drugs_en

${ }^{31}$ European Monitoring Centre for Drugs and Drug Addiction, Slovakia Country Drug Report 2018, http://www.emcdda.europa.eu/countries/drugreports/2018/slovakia/drug-use_en 
imprisonment (3-5 years), home imprisonment and community service. The penalty of imprisonment up to 10 years may be imposed for drug trafficking, supply or production of drugs. The penalties may increase to a range of 1015 years' imprisonment or 15-20 years, depending on the value involved and aggravating circumstances (repeat offence, the involvement of minors). If the crime was committed in the context of an organized group, it may be up to 25 years. In addition, automatic imprisonment for 25 years or even life sentence may be imposed in case of three convictions for certain serious offences. ${ }^{32}$

Within the Ministry of Health, there is the Department of Drug Strategy Coordination and Monitoring of Drugs which represents the national focal point for The European Monitoring Centre for Drugs and Drug Addiction (EMCDDA) as one of the EU's decentralized agencies. ${ }^{33}$ The main function of the Department is to oversee the coordination and implementation of the national drugs strategy. We can also find a unit dealing with institutional and international relations and information transfers related to drug issues within this Department.

In terms of prevention, The National Anti-Drug Strategy for years 20132020 defines the main objectives and framework for drug prevention in the Slovak Republic. Two main objectives are increasing the quality and improving the effectiveness of prevention activities, with a focus on addressing risk factors leading to the initiation of substance use. Prevention is embedded in the activities of numerous institutions representing the education, health, social affairs and family, and criminal justice sectors. ${ }^{34}$

Some stakeholders play a major role in drug abuse prevention. Ministries are responsible for implementing universal prevention programmes in school settings. The main activities in schools are focused on alcohol, smoking, illicit drugs, and risk behavior. Besides, community and Non Governmental Organizations (NGOs) also involved in such an issue. Community prevention programmes are targeted at recreational activities, such as organizing summer camps and sports activities for young people and children within leisure centers while NGOs play an important role in prevention activities across the country. The state and other institutions in Slovakia try to put emphasis especially on sufficient education in the field of drugs, at a young age, thus prevent their abuse, production or trafficking at the time of maturity.

32 The 2014 National Report Year (2013 Data) to the EMCDDA by the Reitox national Focal Point Slovakia New Development and Trends , 13, http://www.emcdda.europa.eu/system/files/publications/1010/14NR_EN_1st_prn.pdf

${ }^{33}$ Ibid, 12.

34 Ministertvo Zdravotnictva Solvenskej Republiky. National Anti-Drug Strategy of the Slovak Republic for the Period 2013 - 2020. http://www.emcdda.europa.eu/attachements.cfm/att_229784_EN_SK_National\%20antidrugs $\% 20$ strategy\% 20of\% 20the\% 20Slovak\% 20Republic\%202013-2020.pdf 


\subsection{Indonesian Law and Regulations Mandated the Participation of Community to Overcome the Drug Problems}

Law of the Republic of Indonesia No. 35 the Year 2009 concerning Narcotics (hereinafter refer to as Indonesian Narcotics Act), a legislation product jointly adopted by Indonesian President and the National Parliament, regulates the means of community participation in the prevention of narcotics abuses. This law, particularly in Article 104 and 105 regulates that communities have the widest possible opportunity, right, and to contribute and help the prevention and eradication of abuse and illicit Narcotics and Narcotics Precursor. Article 106 of the Indonesian Narcotics Act makes clear that the society rights in efforts to prevent and eradicate abuse, illicit narcotics trafficking, and narcotics precursors are manifested in the form of:

a. seek, obtain and provide information regarding the alleged criminal acts of Narcotics and Narcotics Precursor has occurred;

b. obtain service in finding, obtaining, and provide information on alleged criminal acts of Narcotics and of Narcotics Precursor has occurred, to the law enforcement authorities or the BNN, that handles criminal acts cases of Narcotics and of Narcotics Precursor;

c. submit suggestions and opinions in a responsible manner to the law enforcement authorities or the BNN, that handles criminal acts cases of Narcotics and of Narcotics Precursor;

d. obtain answers to the question about the report, that has been provided to the law enforcement officers or the BNN;

e. obtain legal protection during is concerned exercise their rights or be present in court proceedings.

Article 108 makes clear that community roles, as stipulated in Article 104,105 , and 106, can be formed in a forum that is coordinated by the BNN as regulated by the regulation of Head of BNN. In addition, Article 107 of Indonesian Narcotics Act determines that Communities, if aware of any abuse or illicit of Narcotics and of Narcotics Precursor, can make a report to them. There is no doubt that This law formalizes the link between the community and official authorities or BNN. In order to recognize the role of law enforcement officers and the community, as well as to encourage the further involvement, this law enables the government to give the award to both officers and community who would have been rendering service in efforts to prevent and eradication abuse and illicit of Narcotics and Narcotics Precursor. ${ }^{35}$ Elucidation of Article 55 (1) of this Act also emphasizes the participation of the community, in the context of medical and social

35 Article 109 Law of the Republic of Indonesia No. 35 Year 2009 concerning 
rehabilitation ${ }^{36}$ for those who are narcotics addicts but have not reached the age of 18 (eighteen), to improve the oversight and guidance responsibilities towards the children.

The national administration also made guidelines to local governments to include the participation of the community in the efforts to overcome drug abuse. The Ministry of Home Affairs' Regulation No. 21 Year 2013 on the Facilitation of Narcotics Abuse Prevention, Governor and regent/mayor in facilitating the narcotics abuse prevention carrying out some tasks. These include the enactment of regional regulations regarding narcotics that contain some elements, including community participation, and the increasing of community participation in the context of prevention narcotics abuse. 37

Recently, the Instruction of the President of the Republic of Indonesia No. 6 Year 2018 concerning National Action Plan for Strengthening the Prevention and Eradication of the Misuse and Illicit Circulation of Narcotics and Narcotics Precursors (2018-2019) instructs heads of national ministries and agencies and local governments implement such national action plan. This presidential instruction underlines the needs to take preventive action on community empowerment through the development of community potential in vulnerable and susceptible areas of narcotics and narcotics precursors. ${ }^{38}$ The $\mathrm{BNN}$ is appointed as a responsible agency on the implementation of this action, in cooperation with relevant institutions (ministries and local governments).

\subsection{The Involvement of Customary Village in Eradicating Drug Abuses 2.3.1. Functions of Customary Village in Bali}

Under Indonesian law, village is defined as "a unit of community that has boundaries with the authority to regulate and manage the affairs of government, interests of the local communities based on the community's initiatives, right of origin, and/or traditional rights recognized and respected in the system of government of the Republic of Indonesia." 39 According to

36 Social rehabilitation is an integrated process of recovery physical, mental and social activities in order to enable the former narcotics addicts to pursue their social function in community life. See Article 1 (1) of the Law of the Republic of Indonesia No. 35 Year 2009 concerning Narcotics

37 Article 4 Ministry of Home Affairs's Regulation No. 21 Year 2013 on the Facilitation of Narcotics Abuse Prevention

38 Elucidation of Instruction of the President of the Republic of Indonesia No. 6 Year 2018 concerning National Action Plan for Strengthening the Prevention and Eradication of the Misuse and Illicit Circulation of Narcotics and Narcotics Precursors (2018-2019), Section A.4.b Village

39 Article 1 (1) of Law of the Republic of Indonesia No. 6 Year 2014 concerning 
Article 6 (1) of Law of the Republic of Indonesia No. 6 Year 2014 concerning Village (hereinafter refer to as Indonesian Village Act) the village is classified into two types: desa (village) and desa adat (customary village/traditional village). The first category refers to a village that is regulated by Indonesian law and regulation; while the second category, that is primarily discussed in this paper, refers to a village that basically created by the customary community and upholds customary law and tradition.

Article 103 of the Indonesian Village Act further regulates that the authority of a customary village based on the rights of origins as referred to in Article 19 letter a shall include:

a. regulation and implementation of government based on the original arrangement;

b. regulation and management of communal or customary territories;

c. preservation of the socio-cultural values of the customary village;

d. settlement of customary disputes based on customary law in force in customary villages in areas that are in harmony with human rights principles by prioritizing settlement in consultation

e. the organization of a peace trial for the customary village in accordance with the provisions of the laws and regulations;

f. maintenance of peace and order in customary village communities based on customary law that has been applied in customary village; and

g. the development of the life of customary law in accordance with the socio-cultural conditions of the customary village society.

Subsequently, Article 104 of Indonesian Village Act further regulates that the exercise of authority based on the rights of origin local-scale authority of the customary village as referred to in Article 19 letters a and b, as well as Article 103, shall be governed and administered by the customary village based on the principle of diversity. Moreover, Article 110 Indonesian Village Act states that customary village regulation shall be tailored with the prevailing traditional laws and customs in the customary village to the extent not inconsistent with the provisions of the legislation.

Customary village) in Bali is called as desa pakraman (pakraman village) or desa adat (adat village). As defined in Article 1 (4) of the Regulation of Bali Province No. 3 Year 2001 concerning Desa Pakraman, it is a unit of the customary community in the Province of Bali which has one unit traditions and life manners of Hindu community Hindus from generation to generation in a bondage of Kahyangan Tiga or Kahyangan Desa that have its certain areas and assets and has the right to take care of its household. According to Article 1 (11) of this provincial regulation, customary village may create a codified customary rulesand basic principles that is so called as awig-awig, which is used as a guideline in the 
implementation of Balinese life philosophy of Tri Hita Karana. Awig-awig is a type of customary law that resulted from paruman (the highest level meeting of the customary community). ${ }^{40}$ In addition to its authority to establish awig-awig, customary village may also create perarem. ${ }^{41}$ Perarem reflects the dynamic character of customary law and is evidence of customary law that grows following changes in society. ${ }^{42}$

Article 8 (a) jo Article 1 (12) of this provincial regulation determines that awig-awig is implemented by prajuru desa pakraman (the executive agency). Besides, prajuru has tasks for regulating the arrangement of religious ceremonies at Pakraman village, in accordance with religious literature and each tradition; strive for peace and settlement of customary disputes; represent customary village in acting to perform legal actions both inside and outside the court by the approval of paruman (customary meeting); manage of assets customary village; and foster religious harmony within the region customary village.

The Assembly of Customary Village (Majelis Desa Pakraman/MDP) is a customary institution established by Chapter IX of the Regulation of Bali Province No. 3 Year 2001 concerning Desa Pakraman. This assembly has the task to: ${ }^{43}$ (a) protect customs; (b) give suggestions, suggestions and opinions to various parties both individuals, groups/institutions including the government about the problem customary issues; (c) carry out every decision of paruman according to the rules set; (d) Assist the writing of awigawig; and (e) carry out dissemination on customs and traditions thoroughly. Whatsoever this assembly was established through a provincial regulation, a court decision clarifies that the decision adopted by the Assembly of Customary issued by cannot be regarded as an administrative decision in the meaning of administrative law. ${ }^{44}$

The Assembly of dealing with conducting the following issues: (a) deliberate on various things concerning issues of adat and religion for the benefit of friendship; (b) as mediator in customary cases cannot be resolved at the village level; and (c) help organize religious ceremonies at sub regency, regency/municipality, and province levels.

40 Article 12 (1) jo Article 1 (13) of the Regulation of Bali Province No. 3 Year 2001 concerning Desa Pakraman

41 See elucidation Article 6(c) of Regulation of Bali Province No. 3 Year 2001 concerning Desa Pakraman

42 I Wayan Yuda Krisna, Ni Nyoman Dewi Pascarani and I Ketut Winaya. Partisipasi Perempuan dalam Proses Pembuatan Pararem di Desa Pakraman Panjer, Kecamatan Denpasar Selatan, Kota Denpasar. Citizen Charter 1, no.2 (2015): 1-2. Pakraman

${ }^{43}$ Article 16 (1) of the Regulation of Bali Province No. 3 Year 2001 concerning Desa

44 Decision of Adminisitrative Court of Denpasar No. 05/G/2012/PTUN.DPS, 33. 


\subsubsection{Normative Contents that Enabling Customary Village in Bali to Address the Issue of Drug Abuse}

Article 5 (1) (f) of the Regulation of Bali Province No. 7 Year 2017 Concerning Facilitation of Prevention of Narcotics Abuse determines that Primary prevention, that is the effort to prevent someone from abusing narcotics, can be done by increasing the active role of the community and customary village to help prevent narcotics abuse. Article 15 (1) and (2) jo. Article 8 (c) of this provincial regulation determines that prevention through the community environment is done by empowering community elements consisting of village heads/lurah, hamlet heads, and heads of the customary village to carry out prevention activities against narcotics abuse.

Article 29 further regulates that the Governor in facilitating the prevention of Narcotics abuse can cooperate with:

a. the Provincial National Narcotics Agency and the Regency / City National Narcotics Agency;

b. desa pakraman (customary village);

c. educational institutions;

d. religious institutions;

e. community organization;

f. Youth Organization;

g. professional organization;

h. legal entity business entity; and/or

i. individual.

The elucidation of Article 29 explains that the Governor (of Bali) in collaboration with customary village organize facilitation to prevent Narcotics abuse can advise the Pakraman village to insert the substance of narcotics abuse prevention into awig-awig or perarem. It is a new situation in the life of the customary village that needs to be regulated.

The regulation also makes clear that Assembly of Customary Village (Majelis Desa Pakraman) is involved by the governor in organizing narcotics prevention facilitation. 45 Article 31 further regulates that cooperation (collaboration) is carried out through the following activities: seminar, lokakarya; workshop, performances, arts and culture festivals, outbound, race, community empowerment, community training, scientific papers; and socialization, dissemination, assistance, and technical guidance. Elucidation of this article pays attention to the issue of community empowerment. It explains that such empowerment covers the preparation of curriculum for counselling materials, training, and preparation of extension workers from various elements of the community, including the customary village.

45 Article 30 of the Regulation of Bali Province No. 7 Year 2017 Concerning Facilitation of Prevention of Narcotics Abuse determines. 


\subsubsection{Should Customary Village in Bali Play a Pivotal Role in Addressing Drug Abuse?}

The following part will describe and analyze the knowledge, perception, expression, and expectation of customary village leaders regarding the efforts to combat drug abuse in general and in a specific issue that is the involvement of the customary community. As mentioned in Section 1.3, information was obtained from qualitative questionnaires circulated to some customary village leaders (Bendesa and Klian) in Bali between NovemberDecember 2018. The table below indicates the name and position of the customary village leaders.

Table 1

Detail of Informant

\begin{tabular}{llll}
\hline No & \multicolumn{1}{c}{ Name } & \multicolumn{1}{c}{ Occupation } & $\begin{array}{c}\text { Date of filling in } \\
\text { Questionaire }\end{array}$ \\
\hline 1 & I Made Sarja & $\begin{array}{l}\text { Sekretaris and Bendahara Desa } \\
\text { Pakraman Sidakarya-Denpasar }\end{array}$ & 3 November 2018 \\
\hline 2 & I Nyoman Nariata & Klian Desa Adat Batubayan & 30 November 2018 \\
\hline 3 & Putu Wendra & $\begin{array}{l}\text { Klian/Bendesa Adat Desa } \\
\text { Mengwitani-Badung }\end{array}$ & 1 December 2018 \\
\hline 4 & $\begin{array}{l}\text { I Gusti Made Rai } \\
\text { Dirga }\end{array}$ & $\begin{array}{l}\text { Klian Adat Banjar Taman Griya, } \\
\text { Jimbaran-Badung }\end{array}$ & 2 December 2018 \\
\hline 5 & I Made Budiarta & Bendesa Adat Jimbaran-Badung & 5 December 2018 \\
\hline 6 & I Made Asa & $\begin{array}{l}\text { Bendesa Adat Desa Sulangai, } \\
\text { Petang-Badung }\end{array}$ & 7 December 2018 \\
\hline
\end{tabular}

Source: Manage by author

Most informants are leaders of the customary village located in Badung regency. ${ }^{46}$ Most of them convey their concern and feel anxious about the situation of the increasingly widespread circulation, abuse and narcotics crimes in Bali. ${ }^{47}$ The informants also express their disappointment for the facts that young generations are involved in narcotics circulation, abuse, and crimes. They think that this situation would disrupt the future of the younger generation who are expected to be responsible for national development. I Gusti Made Rai Dirga frankly stated that the increasing

\footnotetext{
${ }^{46}$ Badung regency is the regency that much enjoyed the benefit of tourism industry, comparing to others regencies and municipality in Bali Province

47 I Made Sarja, "Informant Interview Questionnaire," Bali, November 3, 2018; I Nyoman Nariata, "Informant Interview Questionnaire," Bali, November 30, 2018; I Gusti Made Rai Dirga, "Informant Interview Questionnaire," Bali, December 2, 2018; I Made Budiarta, "Informant Interview Questionnaire," Bali, 5 December 2018; and I Made Asa, "Informant Interview Questionnaire," Bali, December 7, 2018.
} 
involvement of youngers in this situation would threat all aspects of traditional and cultural life of the customary village in Bali.

The questionnaires feedback revealed that most customary village leaders appreciated the works done by law enforcement agencies in eradicating narcotics abuse including the hard punishment imposed on perpetrators. ${ }^{48}$ Besides, there are also messages from customary village leaders addressed to law enforcement agencies to intensify and thorough their works due to globalization and technological development 49 and the increasing numbers of population that may potentially expand the spread of drug dealing activities. 50

The above information implies that most customary leaders aware of the agencies responsible for narcotics eradication as well as have knowledge of their activities. The appreciation is given to, as well as abstention of specific critics addressed to, anti-narcotics-State law enforcement agencies may be regarded as a positive perception and acknowledgment to the works of the agencies in concern. The message to intensify the agencies' work may be deemed as moral support and suggestion to the better task of the agency.

Section 1.1 described that there was an aspiration to create Perarem that prohibits the use and selling of narcotics. Perarem, as explained in 2.3.1, is a type of customary legal instrument adopted by customary village community that may include sanction for any violations against the norm. I Made Budiarta, I Made Asa, I Gusti Made Rai Dirga, Putu Wendra, and I Nyoman Nariata have a common understanding that this incorporation is needed to give a deterrence effect and embarrassment to the customary community. I Made Asa supported this aspiration in order to restrain the escalation of narcotics spread to rural areas. Besides, he regarded that customary village members mostly respect customary sanction rather than positive laws. I Gusti Made Rai Dirga thought that Perarem may prevent customary village members to involve in any narcotics crime and if it implements properly, it would support the works of law enforcers. Putu Wendra underlines that the creation of perarem should be discussed with other stakeholders e.g Klian Dinas, law apparatus and government officers.

Interestingly, there is reluctance. I Made Sarja, a Customary village leader, thought that creation of Perarem that prohibits the use and selling of narcotics is not needed. He argues that customary institutions as a supporting element for culture and religion will be very burdened with the task of overcoming the problem of narcotics. He thought the limitation of customary institution besides the society readiness to address this issue. He also feels that, as a Bendesa Adat (customary leader), he does not have a

48 Putu Wendra. "Informant Interview Questionnaire," Bali, December 1, 2018; I Gusti Made Rai Dirga, op.cit.; I Made Budiarta, op.cit.; I Made Asa, op.cit.

49 I Nyoman Nariata, op.cit.

50 I Made Budiarta, op.cit. 
capacity to perform preventive action for narcotics circulation and abuse. He expects law strengthening of the customary community. ${ }^{51}$

Facts show that there is a massive external influence that strongly encourages customary village to create perarem. Such encouragement frankly stated by heads and apparatus of provincial and regency governments, BNN, and civil society groups. It is reasonable to understand why they demand customary village to involve in this efforts as they seem to realize that Balinese peoples, especially members of the customary village, feels that the obeyment to customary rules as stipulated in awig-awig and perarem has psychological and social repression. Most informants welcome and agree to the aspiration and encouragement of external parties. In fact, there have been many customary villages already create anti-drug abuse perarem, indicating the goals of there parties were a success. Whatever so, I Made Sarja's statement seem unpopular as most customary leaders support the involvement of customary village. But if we read Article 8 of Bali Provincial Regulation concerning Desa Pakraman, as discussed in 2.3.1., implementing this program is not the principal task of prajuru. This may be regarded as a reflection that each customary village has its own autonomy.

A repressive measure should be taken by customary village leaders prajuru. For example, they may temporarily isolate the drug abuser and its family in their house or specific location. Some may argue that pecalang or jagabaya, customary police, that responsible for controlling the order and security in the customary village, should be optimally involved in combating drug abuse. But one should be understood that pecalang has a limitation in authority as its main task to enforce the awig-awig and perarem, not the ultimate decision maker.

Furthermore, in case of the drugs circulations and abuses massively occur in the customary village, the leaders and members of the customary village may convene a paruman to impose a customary punishment called as kasepekang. This kind of sanction is regarded as an ultimum remedium under customary law that strongly restricts and limits the rights of the punished person or family. Therefore, in case drug abuser or dealer is a member of customary village, he/she and also his/her family may be imposed kasepekang. There is of course pros and contras: some support kasepekang to be applied for giving deterrence effect, ${ }^{52}$ while some others unwilling by considering that type customary penalty is a human rights violation. This paper would like to argue that the kasepekang should be included as one of the sanctions in the anti-drug perarem. It will keep the ethics and morality as well as will definitely give deterrence effect to all

\footnotetext{
51 I Made Sarja, op.cit.

52 See I Made Sumada, op.cit,. 513-514.
} 
customary village members. Simply, all family will keep eyes to prevent its members would involve in any drugs abuse.

\section{Conclusion}

The 'global war on narcotics abuse' is implemented in various ways by countries. In Indonesia, actions were not only taken by State organs e.g the National Anti-Narcotics Agency of the Republic of Indonesia (Badan Narkotika Nasional/BNN), but also involved many stakeholders. An interesting alternative approach can be seen in Bali Province, where many customary villages (desa pakraman), due to their awareness as well as in responding to external encouragement, voluntarily participated in supporting the government actions.

As what has been discovered in this research, most customary village leaders appreciated the works done by law enforcement agencies in eradicating narcotics abuse including the hard punishment imposed on perpetrators. Interestingly, there is a massive effort to transform the antinarcotics agenda into customary norms as stipulated in written customary law, so-called awig-awig and perarem. There have been many customary villages modified their perarem to prohibit the use and selling of narcotics as well as include the sanction to be imposed on those who violate it. This clearly indicates their awareness to work hand in hand with the official government to address such a serious problem. In contrast, there is still an opposing opinion, urging customary village should not take this extra work. This non-mainstream view tends to argue that combating drug abuse is the job of government officials, and therefore, suggests customary structure to merely focus on organizing cultural activities as originally mandated.

There should be no hesitance to adopt a repressive measure by customary village leaders. The imposing of temporary isolation or even kasepekang, as an ultimum remedium that strongly restrict and limit the rights of the punished person or family, may be executed. The customary community should open their eyes that current legal and societal problems can not be dealt with only by using a traditional means. They should realize that customary structures and instruments could optimally support the measures taken by the governments.

\section{Acknowledgement}

Authors express a great appreciation to A.A.P Ramaduffa Okabay N., Ayu Trisna, Chandra Wirawan, I P Destra Wirawan, Krisna Bagaskara D, and Kadek Widhi Pradnya Gita for their generous efforts in collecting information related to this research. 


\section{BIBLIOGRAPHY}

\section{Book}

Rexed, Bror, Ken Edmondson, Inayat Khan and Robert J. Samsom. "Guidelines for the Control of Narcotic and Psychotropic Substances: In the Context of the International Treaties." Geneva: WHO, 1984.

Suhartama, I Putu and BNN Team. Pandangan Agama Hindu Tentang Bahaya Penyalahgunaan Narkoba. Jakarta: Deputi Bidang Pencegahan Badan Narkotika Nasional, 2017

\section{Journal Article}

Haniyah and M. Hidayat. Juridical Review of Decriminalization on Efforts to Cut Drugs Users' Addiction In Indonesia. Yurisdiksi: Jurnal Wacana Hukum dan Sains 11, no.1 (2018): 1-12.

Imran, Muhamad Amin. Hubungan Fungsional Badan Narkotika Nasional dengan Lembaga Pemasyarakatan dalam Penanganan Narkotika di Lembaga Pemasyarakatan. Jurnal IUS-Kajian Hukum dan Keadilan 1, no. 2 (2013): 327-345.

Pasaribu, Restiana. Fight Narcotics With Community Strengthening: Crime Control Management by Community Policing. Journal of Indonesian Legal Studies 3, no.2(2018): 237-252. https://doi.org/10.15294/jils.v3i02.27533.

Sari, Risa Andika, Suhaimi Suhaimi, and Muazzin Muazzin. "Upaya Terpadu Pencegahan dan Pemberantasan Penyalahgunaan Peredaran Gelap Narkotika di Lapas Klas II A Banda Aceh dan Rutan Klas II B Sigli." Syiah Kuala Law Journal (SKLJ) 2, no. 1 (2018): 152-169. https://doi.org/10.24815/sklj.v2i1.10593

Sumada, I. Made. "Collaboration Policy of Regional Office of National AntiNarcotics Agency with Local Wisdom (Perarem Desa Pekraman) In Bali Handling Drug Abuse." In International Conference on Business, Economic, Social Science and Humanities (ICOBEST 2018). Atlantis Press, 2018: 510-514.

Yuda Krisna, I Wayan, Ni Nyoman Dewi Pascarani and I Ketut Winaya. Partisipasi Perempuan dalam Proses Pembuatan Pararem di Desa Pakraman Panjer, Kecamatan Denpasar Selatan, Kota Denpasar. Citizen Charter 1, no.2 (2015):1-6.

\section{National Law and Regulation of the Republic of Indonesia}

Law No. 1 Year 1946 concerning the Criminal Code (Indonesian Criminal Code)

Law of the Republic of Indonesia No. 35 Year 2009 concerning Narcotics

Law of the Republic of Indonesia No. 6 Year 2014 concerning Village

Instruction of the President of the Republic of Indonesia No. 6 Year 2018 concerning National Action Plan for Strengthening the Prevention and Eradication of the Misuse and Illicit Circulation of Narcotics and Narcotics Precursors (2018-2019) 
Ministry of Home Affairs' Regulation No. 21 Year 2013 on the Facilitation of Narcotics Abuse Prevention

Regulation of Bali Province No. 3 Year 2001 concerning Desa Pakraman Regulation of Bali Province No. 7 Year 2017 Concerning Facilitation of Prevention of Narcotics Abuse determines.

\section{Other Documents}

UNODOC. Executive Summary Conslusions and Policy Implications. World Drug Report 2018. Austria: United Nations Publications, 2018. https://www.unodc.org/wdr2018/prelaunch/WDR18_Booklet_1_EXS UM.pdf

UNODOC. International cooperation against the world drug problem Report of the Secretary-General to the United Nations General Assembly A/73/135. United Nations Publications, 1999. https://www.unodc.org/documents/commissions/CND/Drug_Resolu tions/1990-1999/1999/ECOSOC_Res-1999-30.pdf

The 2014 National Report Year (2013 Data) to the EMCDDA by the Reitox national Focal Point Slovakia New Development and Trends , 13, http:/ / www.emcdda.europa.eu/system/files/publications/1010/14N R_EN_1st_prn.pdf

Ministertvo Zdravotnictva Solvenskej Republiky. National Anti-Drug Strategy of the Slovak Republic for the Period 2013 - 2020. http://www.emcdda.europa.eu/attachements.cfm/att_229784_EN_SK National\%20antidrugs\%20strategy\%20of\%20the\%20Slovak\%20Republic\%2020132020.pdf

\section{Court Decision}

Decision of Administrative Court of Denpasar No. 05/G/2012/PTUN.DPS,

\section{Interview}

Asa, I Made. "Informant Interview Questionnaire," Bali, December 7, 2018 Budiarta, I Made. "Informant Interview Questionnaire," Bali, 5 December 2018

Dirga, I Gusti Made Rai. "Informant Interview Questionnaire," Bali, December 2, 2018

Nariata, I Nyoman. "Informant Interview Questionnaire," Bali, November 30, 2018

Sarja, I Made. "Informant Interview Questionnaire," Bali, November 3, 2018

Wendra, Putu. "Informant Interview Questionnaire," Bali, December 1, 2018

\section{Website Content}

10 Desa Pakraman Ditarget Punya Pararem Anti Narkoba. Nusabali.com. Last modified June 23, 2018. https:/ / www.nusabali.com/berita/32557/10-desa-pakramanditarget-punya-pararem-anti-narkoba

Bali Darurat Narkoba? 1.488 Desa Diminta Bentuk Perarem Narkoba. Tribun-Bali.com. Last modified August 22, 2017. 
http://bali.tribunnews.com/2017/08/22/bali-darurat-narkoba-1488desa-diminta-bentuk-perarem-narkoba

Busrah Ardans, Angka Kasus Narkoba di Denpasar Naik 120 Persen, Ini Penjelasan Pihak Polda Bali. Tribun Bali.Com. Last modified August 16, 2018. http://bali.tribunnews.com/2018/08/16/angka-kasusnarkoba-di-denpasar-naik-120-persen-ini-penjelasan-pihak-polda-bali

European Monitoring Centre for Drugs and Drug Addiction, Slovakia Country Drug Report 2018, http://www.emcdda.europa.eu/countries/drug-

reports/2018/slovakia/drug-use_en

European Union. European Monitoring Centre for Drugs and Drug Addiction (EMCDDA). europa.eu. https://europa.eu/european-union/abouteu/agencies/emcdda_en

European Union, Migration Affairs, EU's Response to Drugs, https://ec.europa.eu/home-affairs/what-we-do/policies/organizedcrime-and-human-trafficking/drug-control/eu-response-to-drugs_en

Gembong Ismadi, PHDI Jembrana Dukung Penyalahgunaan Narkotika Masuk Peraturan Adat, Antara Bali. Last modified October 3, 2018. https://bali.antaranews.com/berita/132558/phdi-jembrana-dukungpenyalahgunaan-narkotika-masuk-peraturan-adat

Mantap! Dua Kilogram Sabu dan Ribuan Pil Koplo Dimusnahkan Kejari Jembrana. Baliberkarya.com. Last modified September 28, 2018. https://baliberkarya.com/index.php/read/2018/09/28/2018092800 03/Mantap-Dua-Kilogram-Sabu-dan-Ribuan-Pil-Koplo-DimusnahkanKejari-Jembrana.html

Nusa Bali. BNN Resmikan 7 Desa Bebas Narkoba dan 16 Perarem Anti Narkoba di Gianyar. Skanaa.com. Last modified November 16, 2018. https://www.skanaa.com/en/news/detail/bnn-resmikan-7-desabebas-narkoba-dan-16-perarem-anti-narkoba-di-gianyar/nusabali

Penetapan desa pakraman jelengkung sebagai desa bersih narkoba. Balitribune.co.id. Last modified October 3, 2018. http:/ / balitribune.co.id/content/penetapan-desa-pakramanjelengkung-sebagai-desa-bersih-narkoba

Perarem Anti Narkoba Persempit Ruang Gerak Pengedar di Desa Pekraman. Beritabali.com. Last modified November 15, 2018. https: / / beritabali.com/read/2018/11/15/201811150015/Perarem-

Anti-Narkoba-Persempit-Ruang-Gerak-Pengedar-di-DesaPekraman.html

PHDI Jembrana dukung penyalahgunaan narkotika masuk peraturan adat. Antaranews.com. Last modified October 3, 2018. https://bali.antaranews.com/berita/132558/phdi-jembrana-dukungpenyalahgunaan-narkotika-masuk-peraturan-adat

Suhendi Adi. Hukum Adat Lebih Ditakuti Warga Bali Dibanding Hukum Positif. Tribunnews.com. Last modified March 6, 2014. http://www.tribunnews.com/nasional/2014/03/06/hukum-adatlebih-ditakuti-warga-bali-dibanding-hukum-positif

Suyatra, I Putu. Sudah 42 Desa di Badung Masukkan Narkoba ke AwigAwig dan Pararem. baliexpress.jawapos.com. Last modified November 
22 ,

2017.

https://baliexpress.jawapos.com/read/2017/11/22/28579/sudah42-desa-di-badung-masukkan-narkoba-ke-awig-awig-dan-pararem Widyaswara, I Wayan Erwin, Peredaran Narkoba di Bali Kian Mengkhawatirkan, Anak-anak Jadi Kurir Narkoba, Tribun Bali.Com. Last modified July 31 , 2018.

http://bali.tribunnews.com/2018/07/31/peredaran-narkoba-di-balikian-mengkhawatirkan-anak-anak-jadi-kurir-narkoba 